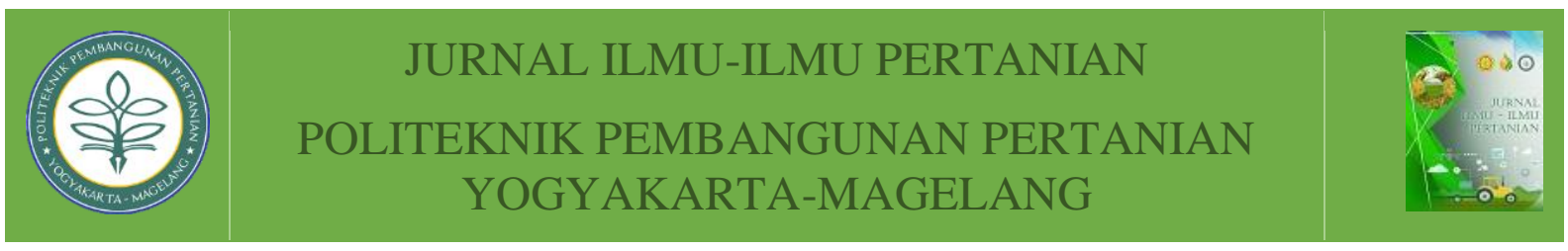

\title{
PENGARUH TAKARAN ZEOLIT DI LAHAN SUBOPTIMAL TERHADAP HASIL DUA VARIETAS BAWANG MERAH
}

\author{
Rajiman $^{1}$, Kodrad Winarno ${ }^{2}$, dan Sutiman $^{3}$ \\ ${ }^{1}$ Politeknik Pembangunan Pertanian Yogyakarta Magelang, Yogyakarta, 55167 \\ ${ }^{2}$ Pusat Pendidikan Pertanian, Jakarta, Indonesia, 12550 \\ ${ }^{3}$ Politeknik Pembangunan Pertanian Yogyakarta Magelang, Yogyakarta, 55167
}

$\begin{array}{lll}\text { Received } & : \text { February } 25^{\text {th }}, 2021 \\ \text { Accepted } & : \text { May } 21^{\text {st }}, 2021 \\ \text { Published } & : \text { June } 17^{\text {th }}, 2021 \\ \text { Copyright Notice } & : \text { Authors retain copyright and grant the journal right of first } \\ \text { c) publication with This work is licensed under a Creative Commons } & \text { Attribution-Non Commercial 4.0 International License. }\end{array}$

ABSTRAK: Penelitian ini bertujuan untuk mengetahui pengaruh zeolit di lahan suboptimal terhadap kemampuan menahan lengas tanah dan hasil dua varietas bawang merah. Penelitian telah dilaksanakan di Kebun Sempu, Wedomartani, Ngemplak, Sleman. Penelitian dilaksanakan mulai bulan Oktober - Desember 2019. Metode penelitian menggunakan Rancangan Petak Terbagi dengan 3 ulangan. Faktor 1 sebagai main plot adalah varietas bawang merah (B) yang terdiri : Crok kuning (B1) dan Bima Brebes (B2). Faktor 2 sebagai sub plot adalah Takaran Zeolit ( $Z$ ) yang terdiri : O ton.ha-1 (Z0), 5 ton.ha-1 (Z1), 10 ton.ha1 (Z2), 15 ton.ha-1 (Z3) dan 20 ton.ha-1 (Z4). Faktor 3 sebagai Sub sub plot adalah ukuran Zeolit (P), yang terdiri : 10 mesh (P1), 20 mesh (P2), dan 40 mesh (P3), Parameter yang diamati adalah kadar lengas (titik layu permanen, kapasitas lapangan, kemampuan menahan lengas tanah), tinggi tanaman, jumlah daun, jumlah umbi per rumpun, bobot segar umbi dan daun per hektar, bobot kering jemur matahari per hektar, dan jumlah umbi per rumpun. Data tanah dianalisis deskriptif dan data tanaman dianalisis dengan sidik ragam dan DMRT $5 \%$.. Hasil penelitian menunjukkan bahwa peningkatan takaran Zeolit secara deskriptif mampu meningkatkan kadar lengas (titik layu permanen, kapasitas lapang dan kemampuan menahan lengas tanah). Perlakuan takaran zeolit nyata berinteraksi dengan varietas. Peningkatan takaran zeolit terhadap varietas nyata berpengaruh terhadap tinggi tanaman, jumlah daun, bobot segar umbi dan daun per hektar, bobot kering jemur matahari per hektar, dan jumlah umbi per rumpun.

Kata Kunci : Zeolit, Bawang Merah, Lengas.

ABSTRACT: This study aims to determine the effect of zeolite in suboptimal land on the capacity to hold soil moisture and yield of two shallot varieties. The research has been carried out in Kebun Sempu, Wedomartani, Ngemplak, Sleman. The research was carried out from October to December 2019. The research method used a Split Plot Design with 3 replications. 
Factor 1 as the main plot is the shallot variety (B) which consists of: Crok kuning (B1) and Bima Brebes (B2). Factor 2 as a subplot is the Zeolite (Z) measure which consists of: 0 ton.ha-

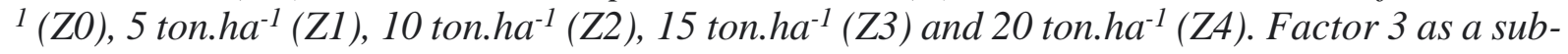
sub plot is the size of the Zeolite (P), which consists of: 10 mesh (P1), 20 mesh (P2), and 40 mesh (P3). The observation parameters consist of moisture content (permanent wilting point, field capacity and soil moisture holding capacity), plant height, number of leaves, number of tubers per clump, fresh weight of tubers and leaves per hectare, sun dry weight per hectare, and number of tubers per clumps. The moisture content data were analyzed descriptively and plant data were analyzed by means of variance and DMRT 5\%. The results showed that increasing zeolite dose descriptively increased moisture content (permanent wilting point, field capacity and soil moisture holding capacity). The treatment of zeolite dose significantly interacted with the varieties. The increase in zeolite dose on varieties significantly affected plant height, number of leaves, fresh weight of tubers and leaves per hectare, sun dry weight per hectare, and number of tubers per clumps.

Keywords : Zeolite, Shallot, Moisture.

\section{PENDAHULUAN}

Secara umum produktivitas bawang merah yang berasal dari benih umbi di Indonesia masih tergolong rendah yaitu kurang dari 12 ton/ha. Menurut BPS (2016) bahwa produktivitas bawang merah di Indonesia tahun 2015 sebesar 10,06 ton/ha dan menurun dibandingkan tahun 2014 sebesar 10,22 ton/ha. Sementara itu, produktivitas bawang merah dengan biji rata-rata mencapai 14,67 ton/ha, dengan distribusi antara 7,5-22 ton/ha. Hasil penelitian Basuki (2009) bahwa produktivitas bawang merah Tuk Tuk yang ditanam di Brebes mampu memberikan daya hasil lebih dari 30 ton/ha berat brangkasan atau lebih besar dari 27 ton/ha berat protolan. pemenuhan produksi bawang merah dapat memanfaatkan lahan suboptimal.

Lahan suboptimal merupakan lahan yang telah mengalami degradasi yang mempunyai kesuburan yang rendah dan tidak mampu mendukung pertumbuhan tanaman secara optimal. Salah satu lahan suboptimal adalah jenis tanah regosol.

Tanah regosol memiliki hambatan utama berupa sifat fisika, kimia dan biologi tanah dalam pengembangan usahatani, khususnya bawang merah. Sifat fisika yang menjadi penghambat adalah drainase dan porositas serta belum membentuk agregat sehingga peka terhadap erosi (Munir, 1996). Menurut Putinella (2014) bahwa tanah Regosol didominasi oleh fraksi pasir $(82,62 \%)$ diikuti oleh fraksi debu $(13,16 \%)$ dan fraksi liat $(4,22 \%)$ sehingga termasuk dalam kelas tekstur pasir berlempung. Tanah dengan tekstur berpasir memiliki faktor pembatas untuk budidaya pertanian berupa struktur tanah lepas-lepas, kemampuan memegang air rendah, infiltrasi dan evaporasi yang tinggi, tingkat kesuburan yang rendah dan bahan organik sangat rendah. Sifat fisika tersebut mengakibatkan rendahnya ketersediaan air bagi tanaman dan secara alamiah tidak cocok untuk budidaya bawang merah, sehingga tingkat produktivitas bawang merah di tanah regosol rendah.

Upaya perbaikan sifat fisika tanah regosol untuk usahatani dapat dilakukan dengan pemberian pembenah tanah. Pembenah tanah bertujuan untuk memperbaiki sifat fisika dan kimia tanah. Pemberian pembenah tanah diharapkan dapat mempercepat agregasi tanah, mengurangi pelindian hara dan meningkatkan daya menahan air. Tujuan penggunaan bahan pembenah tanah adalah: 1. Memperbaiki agregat tanah, 2 . Meningkatkan kapasitas tanah menahan air 
(water holding capacity), 3. Meningkatkan kapasitas pertukaran kation (KPK) tanah dan 4. Memperbaiki ketersediaan unsur hara tertentu. Pembenah tanah dapat berupa alami maupun sintetis. Pembenah alam alami antara lain zeolit, pupuk kandang, tanah lempung, sedimentasi dll.

Beberapa bahan pembenah tanah yang dapat ditemukan berupa zeolit dan pupuk kandang. Zeolit merupakan bahan alam mineral silikat yang memiliki KTK tinggi (120-180 meq/100g), memiliki bobot isi sekitar 2,0 g/cm3 dan berongga dengan ukuran rongga sesuai dengan ukuran ion amonium sehingga zeolit dapat menyerap ion amonium sebelum berubah menjadi nitrat. Mineral zeolit dapat meningkatkan efisiensi pupuk nitrogen. Sebagai bahan pembenah tanah, jumlah zeolit yang perlu diberikan sekitar 10-20 ton/ha. Zeolit memiliki KTK dan kemampuan menjerap ion amonium tinggi serta berstruktur porous dapat dimanfaatkan sebagai bahan pembenah tanah khususnya pada tanahtanah yang mempunyai KTK rendah seperti Oxisol, Ultisol, dan sebagian Inceptisol (Suwardi, 2009).

Menurut Al Busaidi et al. (2008) bahwa penggunaan zeolit sebagai bahan pembenah tanah sangat efektif pada tanah salin, karena mampu memperbaiki produksi dan ketersediaan air yang berkelanjutan. Disamping itu zeolit dapat berfungsi untuk memperbaiki lingkungan pertumbuhan tanaman.

Menurut Jufri dan Rosjidi, (2013) bahwa penggunaan zeolit pada padi dengan dosis $75-80 \%$ hara $\mathrm{N}$ masih menghasilkan produksi padi yang sama dengan penggunaan pupuk konvensional atau rekomendasi, sehingga pemakaian zeolit dapat menghemat pemakaian pupuk anorganik sebesar $20-25 \%$.

Perbaikan sifat tanah akan berdampak pada peningkatan hasil bawang merah di lahan pasir (Hendrata et al. (2003), Mayun, 2007, Rajiman et al., 2009) dan memacu pertumbuhan tomat (Chou et al., 2002).
Menurut Yulianti et al. (2013) bahwa pemberian zeolit dengan dosis $10 \mathrm{~g} / \mathrm{tan}$, memiliki pertumbuhan tinggi tanaman paling rendah (3-5 MST), jumlah daun paling sedikit (3-5 MST), bobot akar paling rendah (3 dan $6 \mathrm{MST}$ ), bobot tajuk paling rendah (6 MST), bobot total tanaman (basah) paling rendah dan jumlah bunga paling rendah (42 HST), tetapi jumlah dan bobot bintil paling tinggi (3 MST) dibanding tanaman yang diberi zeolit dengan dosis lebih rendah pada tanaman edamame.

Pemecahan masalah budidaya bawang merah di lahan suboptimal membutuhkan teknologi pembenah tanah berupa penggunaan zeolit. Penelitian ini bertujuan untuk mengetahui pengaruh pembenah tanah di lahan suboptimal terhadap kemampuan menahan lengas tanah dan hasil Hasil dua varietas bawang merah.

\section{METODE}

Penelitian telah dilaksanakan di Kebun Sempu, Wedomartani, Ngemplak, Sleman. Penelitian direncanakan mulai bulan Oktober - Desember 2019. Bahan-bahan yang digunakan dalam penelitian ini adalah benih umbi bawang merah, Zeolit, pupuk kandang dan pupuk organik cair. Alat yang digunakan adalah alat budidaya, mistar, timbangan, dan jangka sorong.

Penelitian disusun dalam Rancangan Petak Terbagi dengan 3 ulangan. Faktor 1 sebagai main plot adalah varietas bawang merah (B) yang terdiri : Crok kuning (B1) dan Bima Brebes (B2). Faktor 2 sebagai sub plot adalah Takaran Zeolit ( $\mathrm{Z}$ ) yang terdiri : 0 ton.ha-1 (Z0), 5 ton.ha-1 (Z1), 10 ton.ha-1 (Z2), 15 ton.ha-1 (Z3) dan 20 ton.ha-1 (Z4). Faktor 3 sebagai Sub sub plot adalah ukuran Zeolit $(\mathrm{P})$, yang terdiri : 10 mesh (P1), 20 mesh (P2), dan 40 mesh (P3).

Pelaksanaan Penelitian terdiri dari persiapan lahan, persiapan bibit, pemasangan mulsa, penanaman, pemeliharaan dan penyiangan, dan panen. 
Persiapan lahan dilakukan dengan pengolahan tanah sedalam $20 \mathrm{~cm}$ dengan cara membalikkan tanah dan menggemburkan tanah kemudian dibiarkan selama 1 minggu. Kemudian dilanjutkan dengan pembuatan 3 blok dengan ukuran masing-masing $12,5 \mathrm{~m} \times 9 \mathrm{~m}$. Setiap blok dibuat 2 petak dengan ukuran $6,25 \mathrm{~m} \mathrm{x} 9 \mathrm{~m}$. Setiap petak dibagi menjadi 15 bedengan dengan ukuran $1 \mathrm{~m}$ x 2,7 m. Jarak antar blok dan petak selebar $50 \mathrm{~cm}$ dan jarak antar bedeng $25 \mathrm{~cm}$. Lahan percobaan ditambahkan pupuk kandang dengan takaran $1,5 \mathrm{~kg} / \mathrm{m} 2$.

Pemasangan mulsa dilakukan 2 hari sebelum penanaman dimulai. Sebelum mulsa dipasang semua plot percobaan disiram dengan air yang cukup terlebih dahulu dan dibiarkan selama 1-2 jam, setelah itu mulsa dipasang dengan direkatkan ujungnya menggunakan bambu. Kemudian diberikan lubang penanaman dengan menggunakan pelubang mulsa.

Bibit bawang merah diambil dari umbi yang telah memasuki masa dormansi yaitu telah disimpan 2 bulan setelah panen. Umbi dipilih yang mengkilap, kemudian dipotong $1 / 3$ bagian dari ujung. Pemotongan dilakukan sehari sebelum penanaman. Penanaman umbi bawang merah dilakukan dengan menancapkan umbi sedalam 2-3 cm dengan jarak tanam $15 \mathrm{~cm} \times 15 \mathrm{~cm}$. Umbi ditanam dengan posisi tegak pada lubang tanam sehingga permukaannya rata dengan permukaan tanah, dalam satu lubang tanam terdiri dari 1 bibit bawang merah. Penyiraman pertama dilakukan ketika menjelang tanam, dilanjutkan tepat setelah tanam. Penyiraman bawang merah dilakukan secara rutin pada pagi atau sore hari.

Pemupukan pada budidaya bawang merah hanya menggunakan pupuk organik cair. Pemupukan POC diberikan diberikan setiap satu minggu mulai pada 1-5 MST. Dosis pemupukan adalah 2 cc/liter. Penyiangan bertujuan untuk mengurangi kompetisi antara tanaman bawang merah dengan gulma. Penyiangan dilakukan seawal mungkin dengan cara mencabut gulma.

Panen dilakukan pada saat bawang merah berumur 60 HST (Hari Setelah Tanam) setelah $60 \%$ daun bagian atas menguning dan rebah. Pemanenan dilakukan pada saat cuaca sedang cerah, keadaan tanah benar-benar kering untuk mencegah pembusukan umbi dalam penyimpanan. Pemanenan dilakukan dengan mencabut umbi dari dalam tanah atau dengan cara menyongket dari dalam tanah, kemudian dibersihkan dari kotoran yang menempel.

Pengamatan dilakukan terhadap parameter kadar lengas titik layu permanen, kadar lengas kapasitas lapangan dan kemampuan menahan lengas dengan menggunakan metode gravimetri (abdurachman et al, 2006). Parameter tanaman terdiri pertumbuhan dan hasil, yang terdiri dari tinggi tanaman, jumlah daun, jumlah umbi per rumpun, bobot segar umbi dan daun per Hektar, bobot kering jemur matahari per hektar, jumlah umbi per rumpun.

Analisa data tanah dilakukan dengan deskriptif, sedangkan data pertanaman dianalisis dengan ANOVA dan Uji Duncan pada taraf $5 \%$,

\section{HASIL DAN PEMBAHASAN}

\section{Keadaan Tanah dan Iklim}

Unsur iklim yang diamati adalah suhu udara yang diambil dari BMKG Kabupaten Sleman. Suhu udara rerata harian selama penelitian cukup tinggi yaitu berkisar antara 32-38 ${ }^{\circ} \mathrm{C}$. Pada bulan Oktober suhu berkisar $32-38{ }^{\circ} \mathrm{C}$, suhu rerata $35,5{ }^{\circ} \mathrm{C}$, sedangkan pada bulan November suhu berkisar $33-38^{\circ} \mathrm{C}$, suhu rerata $35,0^{\circ} \mathrm{C}$. Suhu tersebut kurang optimal untuk pertumbuhan bawang merah. Menurut Balitan (2005) bahwa budidaya bawang merah cocok ditanam di daerah dengan suhu udara berkisar antara $25-30{ }^{\circ} \mathrm{C}$. Bawang merah dapat tumbuh dari dataran rendah sampai 
dataran tinggi, tetapi tumbuh optimal di daerah pantai sampai ketinggian 400 meter dari permukaan laut (Arifah, 2000).

Tanah yang telah diberi zeolit mampu memperbaiki kadar lengas pada kapasitas lapangan maupun titik kayu permanen. Pengaruh pemberian zeolit terhadap kadar lengas tidak dilakukan analisis statistik. Peningkatan takaran diikuti dengan peningkatan kadar lengas tanah. Peningkatan kadar lengas juga diikuti dengan peningkatan kemampuan menahan lengas pada tanah. Disamping itu semakin meningkat ukuran zeolit akan menurunkan kadar lengas. hal ini menunjukkan bahwa takaran zeolit akan memperbesar kemampuan tanah untuk menahan lengas pada kapasitas lapangan maupun titik layu permanen. Sejalan dengan penelitian Rajiman (2012) bahwa pemberian pembenah tanah pada tanah regosol telah nyata meningkatkan kadar lengas yang terlihat dari indikator lengas tanah pada titik layu permanen, kapasitas lapang dan daya simpan lengas

Tabel 1. Kadar Lengas pada Perlakuan Pemberian Zeolit

\begin{tabular}{|c|c|c|c|}
\hline \multirow{2}{*}{ Takaran Zeolit } & \multicolumn{2}{|c|}{ Kadar Lengas } & \multirow{2}{*}{$\begin{array}{l}\text { Kemampuan Menahan } \\
\text { Lengas tanah }(\%)\end{array}$} \\
\hline & Kapasitas lapangan $(\%)$ & Titik Layu Permanen (\%) & \\
\hline 0 ton/ha & 7,94 & 3,95 & 3,99 \\
\hline 5 ton/ha & 7,96 & 3,81 & 4,15 \\
\hline 10 ton/ha & 7,95 & 3,90 & 4,05 \\
\hline 15 ton/ha & 9,78 & 4,59 & 5,19 \\
\hline 20 ton/ha & 10,06 & 4,80 & 5,20 \\
\hline \multicolumn{4}{|l|}{ Ukuran Zeolit } \\
\hline 10 mesh & 9,15 & 4,67 & 4,49 \\
\hline 20 mesh & 8,27 & 3,91 & 4,53 \\
\hline 40 mesh & 8,58 & 4,05 & 4,53 \\
\hline
\end{tabular}

\section{Hasil Pertanaman}

Analisis sidik ragam menunjukkan bahwa terdapat interaksi yang nyata antara varietas dan takaran zeolit, namun ukuran zeolit tidak nyata berinteraksi dengan perlakuan yang lain. Sehingga hasil penelitian ini disajikan secara terpisah menjadi ukuran zeolit dan interaksi varietas dengan takaran zeolit.

\section{a.Ukuran Zeolit}

Parameter pertumbuhan tanaman dapat dilihat dari tinggi tanaman dan jumlah daun.
Hasil pengamatan terhadap jumlah daun bawang merah dilakukan pada umur 2- 5 minggu setelah tanam (MST). Hasil pengamatan pengaruh ukuran zeolit terhadap tinggi tanaman dan jumlah daun bawang merah disajikan pada Tabel 2 . Tabel 2 menunjukkan bahwa ukuran zeolit tidak nyata mempengaruhi pertumbuhan tanaman dan jumlah daun bawang merah. Tinggi tanaman dan jumlah daun tertinggi setiap perlakuan ukuran zeolit terjadi pada minggu ke 3, setelah itu mengalami penurunan.

Tabel 2. Pengaruh Ukuran Zeolit Terhadap Tinggi Tanaman (cm) dan Jumlah Daun Bawang Merah

\begin{tabular}{ccccccccc}
\hline Ukuran & \multicolumn{3}{c}{ Tinggi Tanaman (MST) } \\
Zeolit & 2 & 3 & 4 & 5 & 2 & 3 & 4 & 5 \\
\hline 10 mesh & $12,4 \mathrm{a}$ & $22,4 \mathrm{a}$ & $19,8 \mathrm{a}$ & $12,4 \mathrm{a}$ & $13,7 \mathrm{a}$ & $22,4 \mathrm{a}$ & $19,8 \mathrm{a}$ & $13,7 \mathrm{a}$ \\
20 mesh & $12,6 \mathrm{a}$ & $22,9 \mathrm{a}$ & $18,0 \mathrm{a}$ & $12,6 \mathrm{a}$ & $13,9 \mathrm{a}$ & $22,9 \mathrm{a}$ & $18,0 \mathrm{a}$ & $13,9 \mathrm{a}$ \\
40 mesh & $12,4 \mathrm{a}$ & $23,0 \mathrm{a}$ & $20,4 \mathrm{a}$ & $12,4 \mathrm{a}$ & $14,2 \mathrm{a}$ & $23,0 \mathrm{a}$ & $20,4 \mathrm{a}$ & $14,2 \mathrm{a}$ \\
\hline
\end{tabular}

Ket : Angka yang diikuti huruf yang sama pada kolom menunjukkan tidak nyata beda uji Duncan $5 \%$. 
Parameter hasil dan kualitas bawang merah dapat diamati dari bobot segar dan kering jemur bawang merah per hektar, susut bobot jemur dan diameter umbi. Hasil pengamatan terhadap parameter hasil dan kualitas dapat dilihat pada Tabel 3. Tabel 3 menunjukkan bahwa ukuran zeolit tidak nyata mempengaruhi hasil dan kualitas hasil bawang merah. Secara umum dapat dilihat bahwa ukuran zeolit 20 mesh memberikan hasil bobot segar dan kering jemur terbesar serta susut bobot yang terkecil. Namun ukuran zeolit 20 mesh menghasilkan diameter umbi yang terkecil. Menurut Indriyati dan Anas (2013) menyatakan bahwa ukuran 60 mesh lebih efektif dalam mempengaruhi tinggi tanaman, bobot kering bagian atas dan akar tanaman jagung umur 21 hari, serapan $\mathrm{N}$ akar serta KTK tanah nyata lebih tinggi daripada pemberian zeolit-urine dengan ukuran yang lebih halus $(<32$ mesh).

Tabel 3. Pengaruh Ukuran Zeolit Terhadap Hasil Bawang Merah

\begin{tabular}{lcccc}
\multicolumn{1}{c}{ Ukuran Zeolit } & $\begin{array}{c}\text { Bobot Segar } \\
(\text { gram })\end{array}$ & $\begin{array}{c}\text { Bobot Kering } \\
(\text { gram })\end{array}$ & $\begin{array}{c}\text { Susut Bobot } \\
(\%)\end{array}$ & Diameter (mm) \\
\hline 10 mesh & $145,2 \mathrm{a}$ & $117,1 \mathrm{a}$ & $23,7 \mathrm{a}$ & $17,0 \mathrm{a}$ \\
20 mesh & $152,0 \mathrm{a}$ & $123,8 \mathrm{a}$ & $22,2 \mathrm{a}$ & $15,0 \mathrm{a}$ \\
40 mesh & $143,8 \mathrm{a}$ & $115,4 \mathrm{a}$ & $24,3 \mathrm{a}$ & $16,1 \mathrm{a}$ \\
\hline
\end{tabular}

Ket : Angka yang diikuti huruf yang sama pada kolom menunjukkan tidak nyata beda uji Duncan $5 \%$.

Menurut Rajiman (2012) bahwa pemberian pembenah tanah ampas kelapa pada tanah regosol telah nyata meningkatkan kadar lengas yang terlihat dari indikator lengas tanah pada titik layu permanen, kapasitas lapang dan daya simpan lengas, $\mathrm{pH}$ tanah, kandungan $\mathrm{C}$ organik tanah, N, P, K. Perbaikan sifat tanah akan berdampak pada peningkatan hasil bawang merah di lahan pasir (Hendrata et al. (2003), Mayun, 2007, Rajiman et al., 2009). Selanjutnya Al Busaidi et al (2008) menyatakan bahwa penggunaan zeolit sebagai bahan pembenah tanah sangat efektif pada tanah salin, karena mampu memperbaiki produksi dan ketersediaan air yang berkelanjutan. Di samping itu zeolit dapat berfungsi untuk memperbaiki lingkungan pertumbuhan tanaman.

Menurut Jufri dan Rosjidi, (2013) bahwa penggunaan zeolit pada padi dengan dosis 75 - $80 \%$ hara $\mathrm{N}$ masih menghasilkan produksi padi yang sama dengan penggunaan pupuk konvensional atau rekomendasi, sehingga pemakaian zeolit dapat menghemat pemakaian pupuk anorganik sebesar $20-25 \%$.

b. Pengaruh Varietas dan Takaran Zeolit

Perlakuan takaran zeolit nyata berinteraksi dengan varietas bawang merah. Hasil pengamatan terhadap jumlah daun bawang merah dilakukan pada umur 2- 5 minggu setelah tanam (MST). Hasil pengamatan pengaruh pengaruh ukuran zeolit terhadap tinggi tanaman dan jumlah daun bawang merah disajikan pada Tabel 4. Tabel 4 menunjukkan bahwa kemampuan varietas beradaptasi dengan takaran zeolit sangat bervariasi baik tinggi tanaman maupun jumlah daun. Varietas Crok Kuning pada berbagai takaran zeolit memberikan pertumbuhan tanaman yang lebih baik dibandingkan varietas Bima Brebes. Hal ini menunjukkan bahwa Crok kuning memiliki daya adaptasi terhadap lingkungan yang lebih baik. 
P-ISSN: 1858-1226; E-ISSN: 2723-4010

Desember 2020, Vol. 27 No. 2

\begin{tabular}{lrrrrrrcc}
\multicolumn{7}{c}{ Tabel 4. Pengaruh Varietas dan Takaran Zeolit terhadap Tinggi Tanaman (cm) Bawang Merah } \\
\hline Perlakuan & \multicolumn{5}{c}{ Tinggi Tanaman (MST) } & \multicolumn{5}{c}{ Jumlah Daun (MST) } \\
& 2 & 3 & 4 & 5 & 2 & 3 & 4 & 5 \\
\hline B1Z0 & $10,6 \mathrm{~b}$ & $19,3 \mathrm{ab}$ & $18,5 \mathrm{a}$ & $10,6 \mathrm{~b}$ & $14,9 \mathrm{a}$ & $19,3 \mathrm{a}$ & $18,5 \mathrm{~b}$ & $14,9 \mathrm{a}$ \\
B1Z1 & $12,8 \mathrm{a}$ & $18,9 \mathrm{ab}$ & $16,7 \mathrm{~b}$ & $12,8 \mathrm{a}$ & $13,8 \mathrm{a}$ & $18,9 \mathrm{ab}$ & $16,7 \mathrm{c}$ & $13,8 \mathrm{ab}$ \\
B1Z2 & $12,3 \mathrm{a}$ & $19,0 \mathrm{ab}$ & $21,4 \mathrm{a}$ & $12,3 \mathrm{a}$ & $15,1 \mathrm{a}$ & $19,0 \mathrm{ab}$ & $21,4 \mathrm{a}$ & $15,1 \mathrm{a}$ \\
B1Z3 & $11,7 \mathrm{ab}$ & $18,6 \mathrm{ab}$ & $17,6 \mathrm{~b}$ & $11,7 \mathrm{a}$ & $13,1 \mathrm{ab}$ & $18,6 \mathrm{~b}$ & $17,6 \mathrm{~b}$ & $13,1 \mathrm{~b}$ \\
B1Z4 & $10,2 \mathrm{~b}$ & $19,2 \mathrm{ab}$ & $16,1 \mathrm{~b}$ & $10,2 \mathrm{~b}$ & $10,6 \mathrm{~b}$ & $19,2 \mathrm{a}$ & $16,1 \mathrm{c}$ & $10,6 \mathrm{c}$ \\
B2Z0 & $9,4 \mathrm{c}$ & $18,4 \mathrm{~b}$ & $12,6 \mathrm{~d}$ & $9,4 \mathrm{bc}$ & $10,0 \mathrm{~b}$ & $18,4 \mathrm{~b}$ & 12,6 & $10,0 \mathrm{c}$ \\
B2Z1 & $10,5 \mathrm{~b}$ & $20,1 \mathrm{a}$ & $14,0 \mathrm{c}$ & $10,5 \mathrm{~b}$ & $10,9 \mathrm{~b}$ & $20,1 \mathrm{a}$ & $14,0 \mathrm{~d}$ & $10,9 \mathrm{c}$ \\
B2Z2 & $8,2 \mathrm{~d}$ & $17,8 \mathrm{~b}$ & $14,7 \mathrm{c}$ & $8,2 \mathrm{c}$ & $8,7 \mathrm{c}$ & $17,8 \mathrm{~b}$ & $14,7 \mathrm{~cd}$ & $8,7 \mathrm{~d}$ \\
B2Z3 & $9,7 \mathrm{c}$ & $19,5 \mathrm{ab}$ & $15,6 \mathrm{bc}$ & $9,7 \mathrm{~b}$ & $10,9 \mathrm{~b}$ & $19,5 \mathrm{a}$ & $15,6 \mathrm{c}$ & $10,9 \mathrm{c}$ \\
B2Z4 & $8,4 \mathrm{~d}$ & $18,8 \mathrm{~b}$ & $14,3 \mathrm{c}$ & $8,4 \mathrm{c}$ & $8,3 \mathrm{c}$ & $18,8 \mathrm{ab}$ & $14,3 \mathrm{~d}$ & $8,3 \mathrm{~d}$ \\
\hline
\end{tabular}

Ket : Angka yang diikuti huruf yang sama pada kolom menunjukkan tidak nyata beda uji Duncan $5 \%$

Interaksi varietas dan takaran zeolit memberikan hasil dan kualitas yang bervariasi terhadap[ parameter bobot segar dan kering jemur bawang merah per hektar, susut bobot jemur dan diameter umbi. Hasil pengamatan terhadap parameter hasil dan kualitas dapat dilihat pada Tabel 5. Tabel 5 menunjukkan bahwa peningkatan takaran zeolit nyata berpengaruh terhadap bobot segar, bobot kering jemur, susut bobot dan diameter umbi pada varietas Crok Kuning maupun Bima Brebes. Varietas Crok kuning memperoleh bobot segar dan kering yang terbaik pada takaran zeolit 10 ton/ha. Sedangkan varietas Bima memperoleh hasil yang terbaik pada takaran zeolit 20 ton/ha.

Tabel 5. Pengaruh Varietas dan Takaran Zeolit Terhadap Hasil Bawang Merah

\begin{tabular}{cccccc}
\hline Perlakuan & $\begin{array}{c}\text { Bobot Segar } \\
(\mathrm{kw} / \mathrm{ha})\end{array}$ & $\begin{array}{c}\text { Bobot Kering } \\
(\mathrm{kw} / \mathrm{ha})\end{array}$ & $\begin{array}{c}\text { Susut Bobot } \\
(\%)\end{array}$ & $\begin{array}{c}\text { Jumlah Umbi } \\
(\mathrm{mm})\end{array}$ & $\begin{array}{c}\text { Diameter umbi } \\
(\mathrm{mm})\end{array}$ \\
\hline $\mathrm{B} 1 Z 0$ & $133,4 \mathrm{~b}$ & $105,8 \mathrm{~b}$ & $20,3 \mathrm{ab}$ & $12,5 \mathrm{~b}$ & $11,68 \mathrm{~b}$ \\
$\mathrm{~B} 1 Z 1$ & $105,6 \mathrm{~d}$ & $87,0 \mathrm{c}$ & $17,1 \mathrm{a}$ & $11,5 \mathrm{~b}$ & $11,74 \mathrm{~b}$ \\
$\mathrm{~B} 1 Z 2$ & $148,8 \mathrm{a}$ & $125,5 \mathrm{a}$ & $15,8 \mathrm{a}$ & $12,4 \mathrm{~b}$ & $12,49 \mathrm{ab}$ \\
$\mathrm{B} 1 Z 3$ & $127,1 \mathrm{~b}$ & $103,5 \mathrm{~b}$ & $18,5 \mathrm{ab}$ & $9,4 \mathrm{c}$ & $13,86 \mathrm{a}$ \\
$\mathrm{B} 1 Z 4$ & $114,8 \mathrm{c}$ & $88,7 \mathrm{c}$ & $22,5 \mathrm{c}$ & $11,4 \mathrm{~b}$ & $12,11 \mathrm{~b}$ \\
$\mathrm{~B} 2 Z 0$ & $77,5 \mathrm{~d}$ & $54,4 \mathrm{~d}$ & $30,0 \mathrm{~d}$ & $15,0 \mathrm{a}$ & $10,68 \mathrm{c}$ \\
$\mathrm{B} 2 Z 1$ & $147,5 \mathrm{a}$ & $113,4 \mathrm{ab}$ & $23,3 \mathrm{c}$ & $15,0 \mathrm{a}$ & $11,41 \mathrm{~b}$ \\
$\mathrm{~B} 2 Z 2$ & $108,1 \mathrm{~d}$ & $87,0 \mathrm{c}$ & $19,4 \mathrm{ab}$ & $16,0 \mathrm{a}$ & $12,42 \mathrm{ab}$ \\
$\mathrm{B} 2 Z 3$ & $112,0 \mathrm{~d}$ & $97,7 \mathrm{c}$ & $12,5 \mathrm{a}$ & $15,4 \mathrm{a}$ & $12,87 \mathrm{ab}$ \\
$\mathrm{B} 2 Z 4$ & $150,0 \mathrm{a}$ & $126,6 \mathrm{a}$ & $15,6 \mathrm{a}$ & $15,0 \mathrm{a}$ & $12,60 \mathrm{ab}$ \\
\hline
\end{tabular}

Ket : Angka yang diikuti huruf yang sama pada kolom menunjukkan tidak nyata beda uji Duncan $5 \%$. 
Varietas Bima nyata menghasilkan jumlah umbi bawang merah yang lebih besar dibandingkan Crok Kuning. Varietas Bima menghasilkan jumlah tidak nyata berbeda pada berbagai takaran zeolit, namun sebaliknya varietas Crok kuning nyata berbeda diameter umbi pada takaran zeolit yang berbeda.

Varietas Bima cenderung menghasilkan diameter yang tidak berbeda dibandingkan dengan varietas crok kuning. Perlakuan peningkatan takaran zeolit nyata mempengaruhi diameter pada varietas Bima dan Crok Kuning. Varietas crok kuning pada pemberian zeolit 15 ton/ha nyata memberikan hasil diameter yang tertinggi. Hal ini diduga bahwa peningkatan takaran zeolit berpengaruh terhadap ketersediaan kelembaban tanah, sehingga berpengaruh terhadap pembentukan umbi.

\section{SIMPULAN DAN SARAN}

Hasil penelitian menunjukkan bahwa peningkatan takaran Zeolit secara deskriptif mampu meningkatkan kadar lengas (titik layu permanen, kapasitas lapang dan kemampuan menahan lengas tanah). Perlakuan takaran zeolit nyata berinteraksi dengan varietas. Peningkatan takaran zeolit terhadap varietas nyata berpengaruh terhadap tanaman, jumlah daun, jumlah umbi per rumpun, bobot segar umbi dan daun per Hektar, bobot kering jemur matahari per hektar, dan jumlah umbi per rumpun.

\section{PUSTAKA ACUAN}

Abdurachman, A., U Haryati, dan I. Juarsah. (2006). Penetapan Kadar Air Tanah Dengan Metode Gravimetrik. Dalam Kurnia, U., F. Agus dan A. Dariah : sifat Fisika Tanah dan Metode Analisisnya. Balai Besar Litbang dan Sumberdaya Lahan Pertanian. Bogor.131-142

Al-Busaidi, A., T. Yamamoto dan M. Inue. (2008). Effects of Zeolite on Soil Nutrients and Growth of Barley
Following irrigation with Saline Water. Prosiding The3 International Coference on Water Resources and Arid Enviroments.

Arifah, S. M. (2000). Kajian Penggunaan Beberapa Varietas Bawang Merah di Kodya Malang. Laporan Penelitian Universitas Muhammadiyah Malang.

Balitan. (2005). Analisis Kimia Tanah, Tanaman, Air dan Pupuk. Badan Penelitian dan Pengembangan Pertanian, Departemen Pertanian. Bogor.

Chou, S. J., M. M Chou, J.W. Stucki, D Warnock, J. A.Chemler and M.A. Pepple. (2002). Plant Growth in Sandy Soil/Compost Mixture and Commercial Peat Moss both Amended with Illinois Coal Fly Ash. Environmental Quality.

Gardner, F.P., R.B. Pearce, and R.I Mitchel. (1991). Physiology of Crop Plant (Fisiologi Tanaman Budidaya, alih bahasa H. Susilo). UI Press. Jakarta.

Hendrata R, Sutardi, T Martini, B. Arlyna, dan M. Fatchurochim. (2003). Pengkajian Bawang merah, Cabe Merah dan Semangka di Lahan Pasir Pantai Propinsi D.I. Yogyakarta. Laporan Penelitian BPTP.

Mayun, I. A. (2007). Efek Mulsa Padi dan Pupuk Kandang Sapi terhadap Pertumbuhan dan Hasil Bawang Merah di Daerah Pesisir. Agritrop. 26(1): 3334.

Munir. (1996). Tanah-tanah utama Indonesia: karakteristik, klasifikasi dan pemanfaatannya. Pustaka Jaya: Jakarta

Putinella. (2014). Perubahan Distribusi Pori Tanah Regosol Akibat Pemberian Kompos Ela Sagu dan Pupuk Organik Cair. Buana Sain. 14 (2): 123-129.

Rajiman, P. Yudono, E. Sulistyaningsih, dan E. Hanudin. (2009). Pengaruh Amelioran Terhadap Ketersediaan N, P, K Tanah Dan Hasil Bawang Merah Di Lahan Pasir Pantai. Jurnal Agriekstensia. 8(1):49-58. 
Rajiman. (2012). Pemanfaatan Ampas Kelapa dalam Budidaya Bawang Merah pada Tanah Regosol. Jurnal Teknologi. 12 (2):50-65

Jufri dan Rosjidi. (2013). Pengaruh Zeolit dalam Pupuk Terhadap Pertumbuhan dan Produksi Padi Sawah di Kabupaten Badung Bali. Jurnal Sain dan Teknologi. 14 (3): 161-166.

Soekartawi. (1995). Analisis Usaha Tani. Universitas Indonesia Press. Jakarta
Suwardi. 2009. Teknik Aplikasi Zeolit Di Bidang Pertanian Sebagai Bahan Pembenah Tanah. Jurnal Zeolit Indonesia. 8 (1): 33-38.

Yulianti N, A Rahayu, dan Setyono. (2013). Pertumbuhan dan produksi kedelai edamame (Glycine max (L.) Merr.) pada berbagai dosis zeolit dan jenis pupuk nitrogen. Jurnal Pertanian. 4 (2): 82-90.

\section{DOI :}

